\title{
Assessment of Heavy Metals in Sediments of Iloilo Batiano River, Philippines
}

\author{
Brian Gil S. Sarinas, Lorna D. Gellada, Eden B. Jamolangue, Marlon R. Teruñez, \\ and June Raymund Peter V. Flores
}

\begin{abstract}
No study have existed on heavy metals present in the river of Iloilo Batiano, Philippines. Thus, this study was conducted to determine the presence and quantities of heavy metals specifically cadmium, chromium and lead in the sediments of Iloilo Batiano River. Furthermore, water physicochemical parameters were determined such as $\mathbf{p H}$ and temperature, in situ. Three sampling stations were identified adjacent to (1) Batiano Bridge of Oton, Iloilo; (2) Sto. Niño Bridge of Villa, Iloilo City and (3) Calumpang Bridge of Molo, Iloilo City, respectively. Three (two sides and at the center perpendicular to the river) $500 \mathrm{~g}$ surface sediments were collected in each of the sampling station for a total of nine sediment samples stored in a sterile ziplock and were immediately transported at the CAS-ASL of UPV, Miag-ao, Iloilo for the quantification of metals through flame atomic absorption spectrophotometry (FAAS). Available cadmium was below detection limit and it appeared that available $\mathrm{Pb}>\mathrm{Cr}$ in the three points of the river in the three sampling stations. Available chromium and lead have high accumulation in station three (Calumpang Bridge). This study provides information on the heavy metal status of the river, awareness to the public and for further conservation of the river.
\end{abstract}

Index Terms-Cadmium, chromium, heavy metals, Iloilo Batiano River, lead.

\section{INTRODUCTION}

Heavy metal contamination of soil is a natural process but it occurs as rare elements [1]. Production of heavy metals is due to agricultural, industrial [2] and other anthropogenic activities [3] as well as natural events such as rock corrosion and weathering.

Lead is considered as one of the industrial hazards and is considered as one of the dangerous environmental pollutants [4]. Cadmium, on the other hand, is a non-essential heavy metal resulting from agricultural, mining, industrial and even from the exhaust smoke emitted by vehicles [5]. Chromium is also a toxic environmental pollutant which can cause detrimental effects to plants and animals [6], [7].

Heavy metals include cadmium, chromium and lead in water, sediment and green algae (Ulva lactuca). The abundance of heavy metals in sediment was $\mathrm{Cd}>\mathrm{Cr}>\mathrm{Pb}$ among the six different stations at Pulicat Lake, South East India [8]. The concentration of cadmium and chromium was $64.21 \mu \mathrm{g} / \mathrm{g}$ and $28.51 \mu \mathrm{g} / \mathrm{g}$, respectively. Similarly, in an

Manuscript received January 15, 2014; revised March 20, 2014

The authors are with John B. Lacson Foundation Maritime University-Arevalo, Sto. Niño Sur, Arevalo, Iloilo City, Philippines (e-mail bg_sarinas@yahoo.com). assessment of heavy metals in the sediment of the Second Songhua River in China, it was found out that the concentrations of chromium and lead in surface sediment $(0-10 \mathrm{~cm}$ depth) were $2.4-75.4 \mathrm{mg} / \mathrm{kg}$, correspondingly [9].

On the other hand, the presence of heavy metals such as cadmium, lead, mercury and chromium in water, sediment, plankton and fish from Lake Beysehir of Turkey through atomic absorption spectrophotometry was conducted [10]. Results showed that heavy metals found in sediment were $\mathrm{Pb}$ $>\mathrm{Cd}>\mathrm{Cr}>\mathrm{Hg}$. Based on Turkish regulations, cadmium and lead in Lake Beysehir were above the permissible levels for drinking water. Similarly, an assessment of heavy metals in Almendares River sediments in Havana City, Cuba showed that lead concentration was $39.3-189 \mu \mathrm{g} / \mathrm{g}, 84.9-209.7$ $\mu \mathrm{g} / \mathrm{g}$ for chromium and $1.0-4.3 \mu \mathrm{g} / \mathrm{g}$ for cadmium dry weight of sediment [11].

In a study on the potential ecological risk assessment of heavy metals in sediment of Baiyangdian Lake, it was found out that cadmium and lead were very high [12]. Heavy metals in the sediments of Ravi River, Pakistan showed that cadmium concentration ranged from $0.99-3.17 \mu \mathrm{g} / \mathrm{g}$, while chromium concentration ranged from $4.60-57.40 \mu \mathrm{g} / \mathrm{g}$ dry weight basis [13]. Furthermore, investigations on the heavy metals in the sediments of Kaohsiung Harbor, Taiwan revealed that cadmium concentration ranged from $0.1-6.8$ $\mathrm{mg} / \mathrm{kg}, 9.5-470 \mathrm{mg} / \mathrm{kg}$ for lead and $0.2-900 \mathrm{mg} / \mathrm{kg}$ for chromium and the river sediment was classified as concentrated with metals [14]. Evidently, the concentrations of heavy metals in the water, sediment and fish in the middle and lower portions of Yangtze River, China [15] revealed that sediments posed moderate and considerable ecological risk. This was due to or derived from metal processing, electroplating industries, industrial wastewater and domestic sewage. In contrast, heavy metals in the sediments of Danube River such as $\mathrm{As}, \mathrm{Cr}, \mathrm{Cv}, \mathrm{Pb}, \mathrm{Mg}, \mathrm{Ni}$, and $\mathrm{Zn}$ were low except for $\mathrm{Cd}$ that was high in the lower stretch of the river [16].

Moreover, studies on the heavy metal cations in the sediments of Shing Mun River, Hong Kong showed that lead concentration was $0.345 \mathrm{mg} / \mathrm{g}, 0.047 \mathrm{mg} / \mathrm{g}$ for chromium and $0.047 \mathrm{mg} / \mathrm{g}$ for cadmium [17].

Conversely, conducted assessments of metal contaminants in the sediments of Kubanni Zaria, Nigeria explained that 11 metals including chromium were polluting the river out of the 29 metals examined [18].

In this study, the presence and quantities of heavy metals such as cadmium, chromium and lead was conducted in the sediments of Iloilo Batiano River to determine the level of heavy metal contamination based on the Philippine standard value. Since there is no data on the presence of these heavy 
metals in Iloilo Batiano River, this study serves as a baseline study.

\section{MATERIALS AND METHODS}

\section{A. Study Area}

Station 1 is found adjacent at the Batiano Bridge of Oton, Iloilo (10 41'36'N, $122^{\circ} 28^{\prime} 48^{\prime \prime}$ E), Station 2, adjacent at the Sto. Niño Bridge of Yulo Drive, Villa, Iloilo City $\left(10^{\circ} 40^{\prime} 53^{\prime \prime} \mathrm{N}, 122^{\circ} 31^{\prime} 02^{\prime \prime} \mathrm{E}\right)$ and Station 3, adjacent at the Calumpang Bridge of Molo, Iloilo City $\left(10^{\circ} 41^{\prime} 17^{\prime} \mathrm{N}\right.$, $\left.122^{\circ} 32^{\prime} 19^{\prime \prime} \mathrm{E}\right)$.
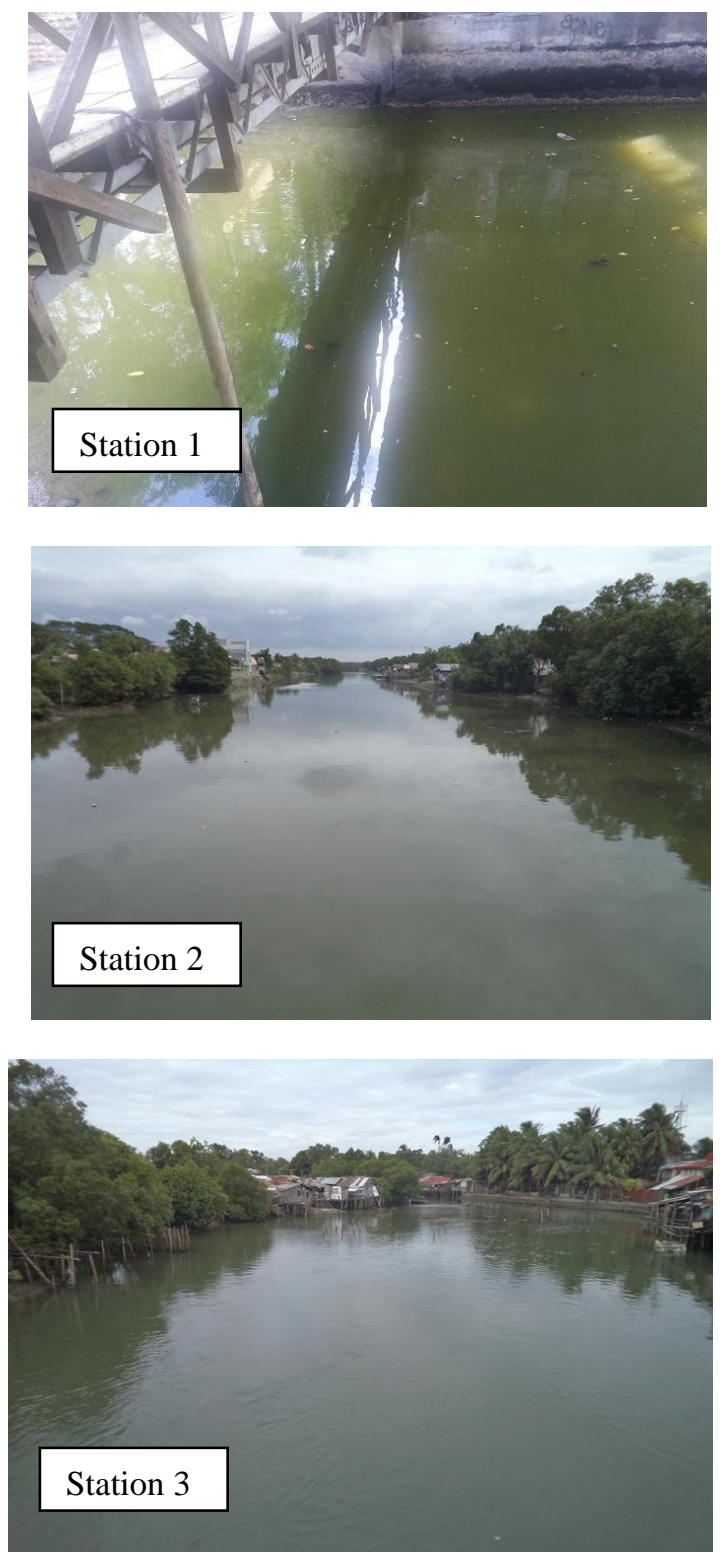

Fig. 1. Sampling stations.

\section{B. Materials}

Materials used were sterile ziplocks, cork borer, $\mathrm{pH}$ paper, thermometer, measuring tape and the flame atomic absorption spectrophotometer (Varian Model 55B) for analysis of sediment samples owned by the CAS-ASL of the University of the Philippines Visayas, Miag-ao, Iloilo.

\section{Data Collection}

Sub-surface soil samples with a depth of $0-5 \mathrm{~cm}$ were collected with the use of cork borer and were placed in sterile ziplock. A total of nine sediment samples in three sampling stations were collected weighing 500 grams each. These sediment samples were immediately transported at the CAS-ASL of University of the Philippines Visayas for analysis of heavy metals.

\section{RESULTS AND DISCUSSION}

Table I presents the water physicochemical characteristics and GPS coordinates of Iloilo-Batiano River. In Station 1, pH value is 8 and the temperature is $27^{\circ} \mathrm{C}$. On other hand, in Station 2, the $\mathrm{pH}$ value is 7.67 and the temperature is $28.67^{\circ} \mathrm{C}$. Lastly, in Station 3, the $\mathrm{pH}$ value is 7.67 and the temperature is $28^{0} \mathrm{C}$.

Table 2 presents the quantities of dissolved heavy metals in Iloilo Batiano River. All total cadmium in all stations showed less than detection value $(<\mathrm{dv})$. In Station 1 , the mean concentration of available chromium is $9.68 \mathrm{mg} / \mathrm{kg}$, $12.93 \mathrm{mg} / \mathrm{kg}$ in Station 2 and $16.34 \mathrm{mg} / \mathrm{kg}$ dry weight in Station 3. Lead, on the other hand, is $13.68 \mathrm{mg} / \mathrm{kg}$ for Station $1,12.73 \mathrm{mg} / \mathrm{kg}$ for Station 2 and $28.06 \mathrm{mg} / \mathrm{kg}$ for Station 3 . The sediments found in the three sampling areas are polluted because it exceeds the standard Philippine value [19].

TABLE I: WATER PHYSICOCHEMICAL CHARACTERISTICS AND GPS COORDINATES OF ILOILO BATIANO RIVER

\begin{tabular}{|c|c|c|c|}
\hline Sampling Stations & "GPS Coordinates & pH & Temperature \\
\hline Batiano Bridge & $\begin{array}{l}10^{\circ} 41^{\prime} 36^{\prime \prime} \mathrm{N} \\
122^{\circ} 28^{\prime} 48^{\prime \prime} \mathrm{E}\end{array}$ & 8 & 27 \\
\hline Sto. Niño Bridge & $\begin{array}{l}10^{\circ} 40^{\prime} 533^{\prime \prime} \mathrm{N} \\
122^{\circ} 31^{\prime} 02^{\prime \prime} \mathrm{E}\end{array}$ & 7.67 & 28.67 \\
\hline Calumpang Bridge & $\begin{array}{l}10^{\circ} 41^{\prime} 17^{\prime \prime} \mathrm{N} \\
122^{\circ} 32^{\prime} 19^{\prime \prime} \mathrm{E}\end{array}$ & 7.67 & 28 \\
\hline
\end{tabular}

\section{CONCLUSIONS}

Available cadmium is less than detectable value in all sampling stations while available chromium and lead exceeds the standard value. This indicates that the river is contaminated with heavy metals. If the sediment will be disturbed, these heavy metals will spread in the water column and will pose hazards to animal, plant life and human health. The results of this baseline study will give awareness to the public not to fish and swim in the area and finally, provide policies for further conservation of the river by the government agencies.

\section{ACKNOWLEDGMENT}

We would like to thank Dr. Mary Lou Lacson Arcelo, President Emeritus and Chairman of the Board of Trustees, John B. Lacson Foundation Maritime University; Dr. Ronald Raymond Lacson Sebastian, Chief Executive Officer and Vice-Chairman, John B. Lacson Foundation Maritime University; Dr. Melchor M. Magramo, Acting Research and Extension Director, John B. Lacson Foundation Maritime University; Arturo D. Paredes, Melchor G. Gito, Geoffrey D. Sondayon, John Yves L. Hechanova, Aurell Joseph Suello 
and Loreto G. Calaliman for the full support extended in this Service Laboratory of the University of the Philippines study and the College of Arts and Sciences - Analytical

Visayas, Miag-ao, Iloilo for the laboratory equipment.

TABLE II: Quantities of AVAILABLE CD, CR ANd PB As Compared to the PhilipPine Standard VAlue

\begin{tabular}{|c|c|c|c|c|c|c|c|c|c|c|c|c|c|}
\hline \multirow{2}{*}{$\begin{array}{l}\text { Metal } \\
(\mathrm{mg} / \mathrm{kg})\end{array}$} & \multicolumn{4}{|c|}{$\begin{array}{c}\text { Station 1 } \\
\text { (Batiano Bridge) }\end{array}$} & \multicolumn{4}{|c|}{$\begin{array}{c}\text { Station } 2 \\
\text { (Sto. Niño Bridge) }\end{array}$} & \multicolumn{4}{|c|}{$\begin{array}{c}\text { Station } 3 \\
\text { (Calumpang Bridge) }\end{array}$} & \multirow[t]{2}{*}{$\begin{array}{c}\text { Philippine } \\
\text { Standard Value }\end{array}$} \\
\hline & Left & Middle & Right & Mean & Left & Middle & Right & Mean & Left & Middle & Right & Mean & \\
\hline $\mathrm{Cd}$ & $<\mathrm{dv}$ & $<\mathrm{dv}$ & $<d v$ & & $<d v$ & $<d v$ & $<d v$ & & $<\mathrm{dv}$ & $<\mathrm{dv}$ & $<\mathrm{dv}$ & & .005 \\
\hline $\mathrm{Cr}$ & 9.64 & 8.51 & 10.9 & 9.68 & 11.07 & 18.27 & 9.47 & 12.93 & 18.61 & 12.91 & 17.51 & 16.34 & .01 \\
\hline $\mathrm{Pb}$ & 13.21 & 10.20 & 17.64 & 13.68 & 10.28 & 16.73 & 11.18 & 12.73 & 24.18 & 12.82 & 47.20 & 28.06 & .01 \\
\hline
\end{tabular}

\section{REFERENCES}

[1] P. Das, S. Samantaray, and G. R. Rout, "Studies on cadmium toxicity in plants: a review," Environmental Pollution, vol. 98, no. 1, pp. 29-36, 1997.

[2] A. I. Sanchez-Fructuoso, A. Torralbo, M. Arroyo, M. Luque, L. M. Ruilope, J. L. Santos, A. Cruceyra, and A. Barrientos, "Occult lead intoxification as a cause of hypertension and renal failure," Nephrology Dialysis Transplantation, vol. 11, pp. 1775-1780, 1996.

[3] M. Beladi, A. Kashani, D. Habibi, F. Paknejad and M. Golshan, "Uptake and effects of lead and copper on three plant species in contaminated soils: role of phytochelatin," African Journal of Agricultural Research, vol. 6, no. 15, pp. 3483-3492, 2011.

[4] P. Sharma and R. S. Dubey, "Lead toxicity in plants," Plant Physiology, vol. 17, pp. 35-52, 2005.

[5] C. D. Foy, R. L. Chaney, and M. C. White, "The physiology of metal toxicity in plants," Annual Review of Plant Physiology, vol. 29, pp. 511-566, 1978.

[6] S. K. Panda and S. Choudhury, "Chromium stress in plants," Brazilian Journal of Plant Physiology, vol. 17 no. 1, pp. 95-102, 2005.

[7] A. K. Shanker, C. Cervantes, H. Loza-Tavera, and S. Avudainayagam, "Chromium toxicity in plants," Environment International, vol. 31, pp 739-753, 2005

[8] S. Kamala-Kannan, R. R. Krishnamoorty et al., "Assessment of heavy metals (cd, cr and pb) in water, sediment and seaweed (ulva lactuca) in the Pulicat Lake, South East India," Chemosphere, vol. 71, no. 7, pp. 1233-1240, 2008.

[9] C. Lin, M. He, Y. Zhou, W. Guo, and Z. Yang, "Distribution and contamination assessment of heavy metals in sediment of the second Songhua River, China," Environmental Monitoring and Assessment, vol. 137, no. 1-3, pp. 329-342, 2008.

[10] A. Altindag and S. Yigit, "Assessment of heavy metal concentrations on the food web of lake Beysehir, Turkey," Chemosphere, vol. 60, no. 4, pp. 552-556, 2005.

[11] S. O. Rieumont, D. D. Rosa, L. Lima, D. Graham, K. D’ Alessandro, J. Borroto, F. Martinez, and J. Sanchez, "Assessment of heavy metal levels in Almendares River sediments-Havana City, Cuba," Water Research, vol. 39, no. 16, pp. 3945-3953, 2005.

[12] Y. Zhou, L. Gui-bao, W. Dian-wu, C. Hui-min, and S. Tong-Zhao, "Pollution and the potential ecological risk assessment of heavy metals in sediment of Baiyangdian Lake," Journal of Agro-environmental Science, vol. 24, no. 5, pp. 945-951, 2005.

[13] A. Rauf, M. Javed, M. Ubaidullah, and S. Abdullah, "Assessment of heavy metals in sediments of the river Ravi, Pakistan," International Journal of Agriculture and Biology, vol. 11, no. 2, pp. 197-200, 2009.

[14] C. W. Chen, C. M. Kao, C. F. Chen, and C. D. Dong. "Distribution and accumulation of heavy metals in the sediments of Kaohsiung harbor, Taiwan," Chemosphere, vol. 66, pp. 1431-1440, 2007.

[15] Y. Yi, Z. Yang, and S. Zhang, "Ecological risk assessment of heavy metals in sediment and human health risk assessment of heavy metals in fishes in the middle and lower reaches of the Yangtze River basin," Environmental Pollution, vol. 159, no. 10, pp. 2575-2585, 2011.

[16] P. Woitke, J. Wellmitz, D. Helm, P. Kube, P. Lepom, and P. Litheraty, "Analysis and assessment of heavy metal pollution in suspended solids and sediments of the river Danube," Chemosphere, vol. 51, no. 8, pp. 633-642, 2003

[17] S. N. Sin, H. Chua, W. Lo, and L. M. Ng, "Assessment of heavy metals cations in sediments of Shing Mun River, Hong Kong," Environmental International, vol. 26, no. 5-6, pp. 297-301, 2001

[18] A. W. Butu and E. O. Iguisi, "Assessment of metal contaminants in River Kubanni Zaria, Nigeria," Research Journal of Environmental and Earth Sciences, vol. 4, pp. 884-889, 2012.

[19] G. S. Su, K. J. Martillano, T. P. Alcantara, E. Ragragio, J. De Jesus, A. Hallare, and G. Ramos, "Assessing the heavy metals in the waters, fish and macroinvertebrates in Manila bay, Philippines," Journal of Applied Sciences in Environmental Sanitation, vol. 4, no. 3, pp. 187-195, 2009.

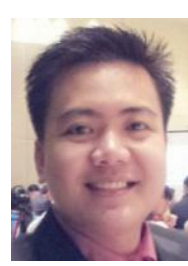

Brian Gil S. Sarinas is a Ph.D. candidate and the in-charge of Research Office in John B. Lacson Foundation Maritime University-Arevalo at Sto. Niño Sur, Arevalo, Iloilo City, Philippines. He finished his M.Sci. in biology at the University of the Philippines Visayas (UPV) and Ph.D. (ongoing) at West Visayas State University, La Paz, Iloilo City, Philippines. His research areas include fungal distribution, isolation, purification and taxonomy, biology education, aquatic or environment-related and maritime-related fields. He has published nine publications. He is currently an associate member of the Department of Science and Technology-National Research Council of the Philippines (DOST-NRCP), member of Philippine Association of Institutions for Research (PAIR) and International Association of Multidisciplinary Research (IAMURE). He had been invited as a speaker in the local, regional, national and international scientific conferences.

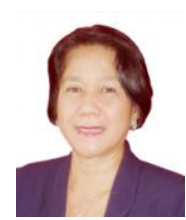

Atty. Lorna D. Gellada is a Ph.D. holder, she finished her doctor of philosophy degree and master degree in education, major in curriculum and instruction from John B. Lacson Foundation Maritime University, West Visayas State University and her bachelor degree of laws at University of Iloilo. She is also a graduate of bachelor degree of science in education, major in elementary education and minor in teaching science also from the then West Visayas State College (formerly Iloilo Normal School) and now the West Visayas State University. She was previously a professor and dean of the College of Education, Central Philippine University, Iloilo City. She also presented various maritime researches abroad. Now, she is the Administrator/DQMR of John B. Lacson Foundation Maritime University-Arevalo, Sto. Niño Sur, Arevalo, Iloilo City, Philippines.

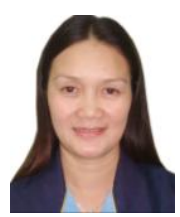

Eden B. Jamolangue is a MA. Ed. She is also a researche and faculty of John B. Lacson Foundation Maritime University-Arevalo at Sto. Niño Sur, Arevalo, Iloilo City, Philippines. She finished her master degree of education at Aklan State University, Philippines. She is very cooperative and hardworking in research endeavors. 


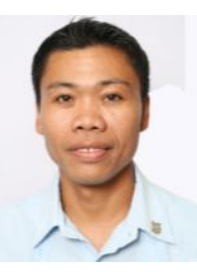

Marlon R. Teruñez is a Ph.D. holder, researcher and faculty of John B. Lacson Foundation Maritime University-Arevalo at Sto. Niño Sur, Arevalo, Iloilo City, Philippines. He finished his Ph.D. in Maritime Education also at John B. Lacson Foundation Maritime University-Arevalo. $\mathrm{He}$ has published three publications and had been invited as speaker in some scientific conferences. An active researcher in the field of environmental research. His current research is on seagrass monitoring at Nueva Valencia, Guimaras, Philippines.
June Raymund Peter V. Flores is a researcher and faculty of John B. Lacson Foundation Maritime University-Arevalo at Sto. Niño Sur, Arevalo, Iloilo City, Philippines. He is currently finishing his master degree at Aklan State University, Philippines. He has published three publications and had been a speaker in some scientific conferences. His current undertaking focuses also on seagrass monitoring at Nueva Valencia, Guimaras, Philippines. 